\title{
Predictability of Atrial Fibrillation in Patients having Coronary Artery Bypass Graft Surgery, Based on Selvester Score
}

\section{Selvester Skoruna Göre Koroner Arter Baypas Greft Cerrahisi Geçiren Hastalarda Atriyal Fibrilasyonun Tahmin Edilebilirliği}

\author{
(D) Dinçer UYSAL ${ }^{1}$, (D) Mevlüt Serdar KUYUMCU² \\ ${ }^{1}$ Süleyman Demirel University Faculty of Medicine, Department of Cardiovascular Surgery, Isparta, Turkey \\ ${ }^{2}$ Süleyman Demirel University Faculty of Medicine, Department of Cardiology, Isparta, Turkey
}

\begin{abstract}
Aim: Patients having coronary artery bypass graft (CABG) surgery are influenced mostly by atrial fibrillation (AF), with the peak incidence of $16-44 \%$. Due to post-operative AF (POAF), patients may be hospitalized for longer periods, require intensive care unit care again, necessitate more healthcare resources and even undergo congestive heart failure or stroke. Recent studies have shown that the size of the ventricular scar might be used as an indicator in the pathophysiology of AF. Selvester score was developed for the measurement of myocardial scar volume in patients with abnormal ventricular conduction, reporting its prognostic value in AF. Thus, we aim to investigate a likely relationship of POAF and the Selvester scoring system.

Materials and Methods: This retrospective study included 180 patients with CABG from 2017 August to 2018 September. The obtained data had been analyzed in separate cohort of patients with POAF $(n=50)$ and with post-operative sinus rhythm (PSR) ( $n=130)$. Intergroup comparisons were made using Selvester scores in particular.

Results: The POAF group had higher Selvester scores $(p<0.001)$, score of SYNTAX ( $p=0.039)$, serum high-sensitivity C-reactive protein levels ( $p=0.026)$, mean age $(p<0.001)$, hypertrophy of left ventricul $(L V H)(p=0.019)$ and hypertension $(p=0.007)$ and decrased ejection fraction (LVEF) ( $p<0.001)$ than the PSR group. Logistic multivariable regression analyses showed that there were an independent association of LVH ( $p=0.041), \operatorname{LVEF}(p=0.004)$, older age $(p=0.008)$ and higher Selvester score $(p<0.001)$ with POAF.
\end{abstract}

Conclusion: Higher scores in Selvester scoring system are closely related to POAF, and Selvester score is a potential indicator for POAF.

Keywords: Post-operative atrial fibrillation, Selvester score, coronary artery bypass graft surgery

ÖZ

Amaç: Koroner arter baypas grefti (KABG) ameliyatı geçiren hastalar, \%16-44 oranında atriyal fibrilasyondan (AF) etkilenmektedirler. Ameliyat sonrası post-operatif AF (POAF) nedeniyle hastalar daha uzun süre hastanede kalabilir, uzamış yoğun bakım hizmetine ihtiyaç duyabilir, daha fazla sağlık kaynağı harcanmasına yol açabilir ve konjestif kalp yetmezliği veya inme geçirebilirler. Son çalışmalar, ventriküler skar boyutunun AF patofizyolojisinde prediktör olarak kullanılabileceğini göstermiştir. Selvester skoru, anormal ventriküler iletisi olan hastalarda miyokardiyal skar hacminin ölçümü için geliştirilmiş ve $\mathrm{AF}^{\prime}$ de prognostik değerini bildirmiştir. Bu nedenle çalışmamızda, POAF ve Selvester puanlama sisteminin olası bir ilişkisini araştırmayı hedefledik.

Gereç ve Yöntem: Bu retrospektif çalışma, Ağustos 2017'den Eylül 2018'e kadar KABG uygulanan 180 hastayı içermektedir. Elde edilen veriler, postoperatif sinüs ritmi (PSR) $(n=130)$ ve POAF $(n=50)$ olan iki ayrı hasta grubunda analiz edilmiştir. Gruplar arası parametreler ve Selvester puanları kıyaslanmıştır.

Bulgular: POAF grubunda Selvester skoru $(p<0,001)$, SYNTAX skoru $(p=0,039)$, serum yüksek sensitif C-reaktif protein düzeyleri $(p=0,026)$, ortalama yaş $(p<0,001)$, elektrokardiyografik sol ventrikül hipertrofisi $(S V H)$ oranı daha yüksek $(p=0,019)$; hipertansiyon $(p=0,007)$ ve ortalama sol ventrikül ejeksiyon fraksiyonunda (SVEF) PSR grubuna göre daha düşük $(p<0,001)$ saptanmıştır. Çok değişkenli lojistik regresyon analizinde SVEF ( $p=0,004)$, SVH $(p=0,041)$, ileri yaş $(p=0,008)$ ve daha yüksek Selvester skoru $(p<0,001)$, POAF için bağımsız risk faktörü olarak saptanmıştır.

Sonuç: Selvester puanlama sistemindeki yüksek puanlar POAF ile yakından ilişkilidir ve Selvester skoru POAF için potansiyel bir gösterge olabilir. Anahtar Kelimeler: Post-operatif atriyal fibrilasyon, Selvester skoru, koroner arter baypas greft ameliyatı

Address for Correspondence: Dinçer UYSAL MD, Süleyman Demirel University Faculty of Medicine, Department of Cardiovascular Surgery, Isparta, Turkey E-mail: drdinceruysal@hotmail.com ORCID ID: orcid.org/0000-0002-8498-9076

Received: 27.10.2020 Accepted: 12.12.2020

๑Copyright 2021 by the Tekirdağ Namık Kemal University Faculty of Medicine / Namık Kemal Medical Journal published by Galenos Publishing House. 


\section{INTRODUCTION}

Patients having coronary artery bypass graft (CABG) surgery are influenced mostly from atrial fibrillation (AF), with the peak incidence of $16-44 \% \%^{1,2}$. Due to post-operative AF (POAF), patients may be longer hospitalized, require intensive care unit again, necessitate more healthcare resources and even undergo congestive heart failure or stroke ${ }^{3-6}$. In order to lower the morbidity and mortality rates from such a frequent complication, preoperative risk factors should essentially be identified along with the development of clinical predictive models and prophylactic strategies ${ }^{7,8}$. In patients under 70 years of age, who undergo $C A B G$, the incidence of $A F$ in the first post-operative year is higher, indicating its association with higher renal dysfunction and infection ${ }^{9-13}$.

For cardiac examination, the twelve-lead electrocardiogram (ECG) is commonly used because of its cost-efficiency, noninvasiveness, reproducibility, quickness, and portability. There are several predictors for the prognosis of AF considering abnormalities on ECG including fragmented QRS or bundle branch block and longer duration of QRS ${ }^{14,15}$. The Selvester model became a novel scoring system of QRS in 1980s, consisting of 32 points corresponding to the sections of left ventricular (LV) mass, about 3\% each (Figure 1) ${ }^{16}$. Additionally, the Selvester score was developed for measurement of myocardial scar volume in patients with abnormal ventricular conduction, reporting its prognostic value in AF. A research has recently shown that ventricular scar size may have a part in the pathophysiology of $\mathrm{AF}^{17}$.

In the light of these findings, we aim in this study to investigate a likely association between POAF and Selvester scoring system.

\section{MATERIALS AND METHODS}

We first retrospectively evaluated a total of 208 patients with a history of on-pump isolated CABG at Süleyman Demirel University, Faculty of Medicine Research and Training Hospital. The exclusion criteria were identified as several risk factors including chronic obstructive pulmonary disease $(n=2)$, valvular heart diseases $(n=5)$, preoperative $A F$ or flutter $(n=8)$, additional surgical intervention $(n=4)$, renal insufficiency $(n=3)$, preoperative inotropic or mechanical support $(n=2)$, and recurrent surgery or emergency coronary surgery $(n=4)$ considering that these could develop AF.

Hypertension was diagnosed immediately for a patient using anti-hypertensive drugs, or after three different measurements at least for a patient with a systolic blood pressure of $\geq 140 \mathrm{mmHg}$ or a diastolic blood pressure of $\geq 90 \mathrm{mmHg}$. Again, for the diagnosis of diabetes mellitus, we considered anti-diabetic medication, or if not, a fasting blood glucose level of $\geq 126 \mathrm{mg} / \mathrm{dL}$. A patient having used statin three months ago was diagnosed with hyperlipidemia, or for total cholesterol levels of $\geq 200 \mathrm{mg} / \mathrm{dL}$. Patients who used to smoke were recorded as smokers even if they quitted following hospitalization.

The Local Ethics Committee approved our study protocol Süleyman Demirel University Faculty of Medicine Clinical Research and Ethics Committee (decision date: 22.10.2020, number: 323), and the patients provided written informed consent individually. We designed and conducted this study in accordance with the Declaration of Helsinki, Good Clinical Practice and International Conference on Harmonization guidelines.

\section{Echocardiography}

Echocardiography was performed in all patients before surgery. Echocardiographic assessment was performed using a VIVID 7 dimension cardiovascular ultrasound system (VingmedGeneral Electric, Horten, Norway) with a $3.5 \mathrm{MHz}$ transducer. The echocardiographic examination was performed in the left lateral decubitus position. Parasternal long- and short-axis views and apical views were used as standard imaging windows. Left ventricular ejection fraction (LVEF) was calculated by using a modified Simpson method. All echocardiographic images were analyzed by an experienced cardiologist.
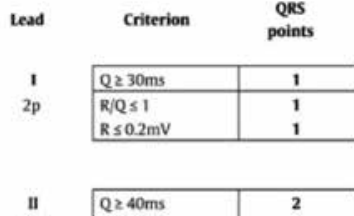

Q $2240 \mathrm{~ms}$
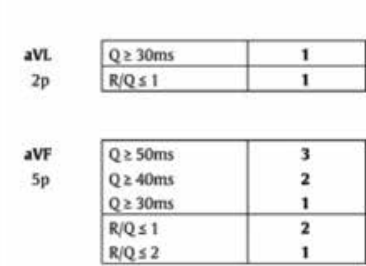

vi (ant)

ip

vi (lat)

$4 p$

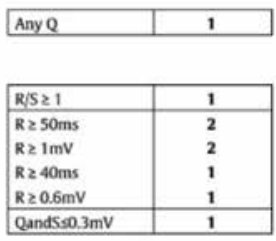

V2 (ant)

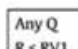

$R<R V I$

Rs $10 \mathrm{~ms}$

$R \leq 0.1 \mathrm{mV}$

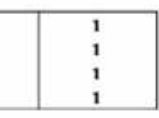

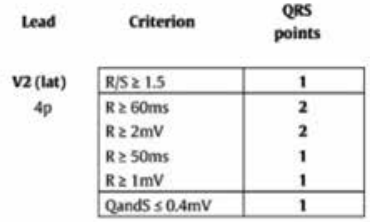

v3

ip

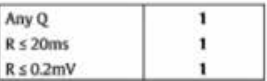

$R \leq 0.2 \mathrm{mV}$

\begin{tabular}{|l|l|}
\hline $\mathrm{Q} \geq 20 \mathrm{~ms}$ & $\mathbf{1}$ \\
\hline$R / \mathrm{Q} \leq 0.5$ & $\mathbf{2}$ \\
$R / S \leq 0.5$ & $\mathbf{2}$ \\
$R / Q \leq 1$ & $\mathbf{1}$ \\
$R / S \leq 1$ & $\mathbf{1}$ \\
$R \leq 0.7 \mathrm{mV}$ & $\mathbf{1}$ \\
\hline
\end{tabular}

vs

\begin{tabular}{|l|l|}
\hline$Q 230 \mathrm{~ms}$ & $\mathbf{1}$ \\
\hline$R / Q \leq 1$ & 2 \\
$R / S \leq 1$ & 2 \\
$R / Q \leq 2$ & 1 \\
$R / S \leq 2$ & 1 \\
$R \leq 0.7 \mathrm{mV}$ & 1 \\
\hline
\end{tabular}

19

\begin{tabular}{|l|l|}
\hline$Q \geq 30 \mathrm{~ms}$ & 1 \\
\hline$R / Q \leq 1$ & 2 \\
$R / S \leq 1$ & 2 \\
$R / Q \leq 3$ & 1 \\
$R / S \leq 3$ & 1 \\
$R \leq 0.6 \mathrm{mV}$ & 1 \\
\hline
\end{tabular}

Figure 1. Selvester score chart 


\section{Selvester QRS Score}

Prior to hospitalization, twelve-lead ECG records were taken using an electrocardiograph (FCP-7541; Fukuda Denshi Co. Ltd, Tokyo, Japan). The 12-lead ECG was recorded at a paper speed of $50 \mathrm{~mm} / \mathrm{s}$ in the supine position. All of the ECGs were scanned and transferred to a personal computer to decrease the error measurements, and then used for $\mathrm{x} 400 \%$ magnification by Adobe Photoshop software. An average value of three readings was calculated for each lead. An experienced cardiologist manually calculated the 32-point Selvester QRS score, based on an algorithm reported in literature (Figure 1) ${ }^{18}$.

\section{Medication, Anesthesia and Surgical Procedure}

Acetylsalicylic acid and clopidogrel were routinely discontinued 5 days before the procedure in all patients. Enoxaparin treatment was started instead. Only beta blockers were preoperatively continued even on the morning of surgery. Angiotensin-converting enzyme (ACE) inhibitors were discontinued from preoperative admission to avoid vasoplegic syndrome. Calcium channel blockers were also stopped preoperatively and the beta-blocker was started or the dose was increased according to blood pressure and heart rate. If only with beta-blocker it was normotensive, no other drug was started. With the recommendation of the guidelines, patients were not given statins before the operation. If there was no drainage in the first 6 hours, acetylsalicylic acid was started, and if there was drainage, it was waited for 24 hours. Beta blocker was given as the first dose at 06:00 in the morning after surgery. Statin started after discharge.

A radial artery catheter was inserted to monitor all patients on whom midazolam $\left(0.05-0.1 \mathrm{mg} / \mathrm{kg}\right.$ ) (Zolamid ${ }^{\circledR}$; Defarma, Tekirdağ, Turkey) was intravenously administered. We induced anesthesia in the patients, using fentanyl by $1-2 \mu \mathrm{g} / \mathrm{kg}$ (Talinat ${ }^{\circledR}$; Vem, İstanbul, Turkey) pentothal by $5-7 \mathrm{mg} / \mathrm{kg}$ (Pental ${ }^{\circledR}$ Sodium, İstanbul, Turkey) and intravenous rocuronium bromide of 0.6 $\mathrm{mg} / \mathrm{kg}$ (Curon ${ }^{\circledR}$, Mustafa Nevzat, İstanbul, Turkey). The Primus ${ }^{\circledR}$ (Draeger Medical, Lübeck, Germany) was utilized to maintain intraoperative mechanical ventilation. Midazolam, fentanyl, and rocuronium were used for the patients to maintain the continuance of anesthesia. We performed standard CABG sternotomy made from medial postion and mild grade hypothermia $\left(32{ }^{\circ} \mathrm{C}\right)$. With the administration of heparin $(300$ $\mathrm{IU} / \mathrm{kg}$ ), an activated coagulation time higher than $400 \mathrm{sec}$. was achieved. The CABG was carried out through cannulation of aortovenous with two-stage. We first placed an X-clamp on the ascending aorta and then induced cardiac arrest using cold cardioplegia (10 to $15 \mathrm{~mL} / \mathrm{kg}$ ) and high level of potassium. To maintain arrest of heart, blood cardioplegia had provided every 15 to $20 \mathrm{~min}$. We established CABG with the help of a roller pump with a membrane oxygenator (Maquet, Getinge group, Restalt, Germany) and an arterial line filter at pump flow rates of 2 to $2.4 \mathrm{~L} / \mathrm{min} / \mathrm{m}^{2}$. Following the preparation of internal thoracic artery and saphenous vein, we constructed distal anastomoses during a single period of total X-clamp and partially clamped the aorta to establish proximal anastomoses. Hot blood shot cardioplegia was released, and the X-clamp was instantly removed. The patients having undergone cardiovascular surgery were transported to the related intensive care unit. Standard procedure for post-operative care was implemented in each patient. Extubation was performed as soon as hemodynamic stability was observed. For a new onset of AF, the first-choice anti-arrhythmic agent was amiodarone for use in the patient.

\section{Post-operative Atrial Fibrillation Assessment}

POAF was defined when AF lasted for at least 30 minutes according to the $\mathrm{ECG}$ report ${ }^{19-21}$. The patients were periodically monitored to make an assessment of AF in the first four postoperative days. Subsequently, 12-lead ECG measurement was carried out 3 times a day until discharge. The patients were also monitored for AF with a 12-lead ECG whenever they described palpitations.

\section{Statistical Analysis}

Utilizing SPSS for Windows version 21.0 (SPSS, Chicago, IL, USA), the mean, standard deviation, rate, and frequency values were used for the statistical analyses. Number of each group was adjusted as more than 25 patients because we calculated the minimum number of individuals that should be sampled with 90\% power and 0.05 type 1 error as at least 46 ( $R$ 3.0.1. open source program). The primary effect variable was determined as one point of Selvester score chart. The normal distribution of continuous variables was assessed using the Kolmogorov-Smirnov test. Parametric data were analyzed with the Student's t-test, and non-parametric data were analyzed with the Mann-Whitney U test. Intergroup comparative analysis was carried out using the chi-square test for categorical variables. Logistic regression model was established to explain the linearity between relevant variables. We used standardized beta coefficients and 95\% confidence intervals, and statistical significance was accepted as a $p$ value of $<0.05$.

\section{RESULTS}

The baseline clinical and demographic characteristics of the study population are shown in Table 1 . There was no difference between the groups in terms of their body mass index, gender, diabetes mellitus, smoking, peripheral vascular disease and cerebrovascular event history status. The mean age $(p<0.001)$ and rate of hypertension $(p=0.007)$ were higher in the POAF group. There was no difference in the use of calcium channel blockers ( $p=0.168)$, beta blockers $(p=0.196), \operatorname{ACE}(p=0.506)$ and anti-aggregates $(p=0.723)$, which are potential drugs that can prevent the development of POAF. 
Electrocardiographic, echocardiographic and surgical characteristics of the groups are shown in Table 2. The POAF group had significantly higher mean SYNTAX scores $(p=0.039)$ and significantly lower mean LVEF $(p<0.001)$. When the left atrium diameter was examined, the diameter was found to be higher in the POAF group, but not statistically significant $(p=0.056)$, The POAF group had significantly higher frequency of ECG-detected left ventricular hypertrophy $(p=0.019)$ as well as higher mean Selvester score $(\mathrm{p}<0.001)$. Normal sinus rhythm was found to be lower in the POAF group. However, it was not statistically significant $(p=0.076)$. When post-operative complications were examined, there was no difference between the groups in terms of pacemaker need $(p=0.900)$, perioperative death $(p=0.8282)$, and ischemic cerebrovascular event $(p=0.504)$. Out of the laboratory parameters, only the high-sensitivity C-reactive protein level had a statistically significant difference between the groups $(p=0.026)$ (Table 3$)$.

The predictors (Table 1-3) of POAF were determined through univariate and multiple linear regression analyses, and the results are shown in Table 4 . In the univariate regression analysis, older age [odds ratio (OR): 1.081; 95\% confidence interval (CI): 1.040-1.124; $\mathrm{p}<0.001]$, hypertension (OR: 3.717; 95\% Cl: 1.370-10.087; $p=0.010$ ), lower LVEF (OR: 0.939; 95\% Cl: $0.908-0.971 ; p<0.001)$, higher high-sensitivity C-reactive protein levels (OR: $1.025 ; 95 \% \mathrm{Cl}: 1.002-1.049 ; \mathrm{p}=0.032$ ), higher Selvester score (OR: 1.524; 95\% Cl: 1.305-1.780; $p<0.001$ ) and left ventricular hypertrophy detected on ECG (OR: 4.295; 95\% Cl: 1.158-15.934; $p=0.029$ ) were significantly associated with POAF. Multiple linear regression analysis demonstrated that older age (OR: 1.068; 95\% Cl: 1.017-1.122; $p=0.008$ ), lower LVEF (OR: 0.939; 95\% Cl: 0.900-0.981; $p=0.004)$, higher Selvester score (OR: 1.602; 95\% Cl: 1.337-1.921; $p<0.001)$ and left ventricular hypertrophy detected on ECG (OR: 8.368; 95\% $\mathrm{Cl}: 1.657-42.255 ; p=0.041)$ were independent predictors of POAF.

There was a statistically significant negative correlation between ejection fraction and Selvester score $(p=0.048, r=-$ 0.521).

\section{DISCUSSION}

In this study, a high Selvester score was significantly associated with POAF, suggesting that along with classical risk factors such as EF and age, Selvester score may be predictive of POAF. Up to $50 \%$ of patients undergoing $C A B G$ have post-operative new arrhythmias ${ }^{22}$. The most common arrhythmias after CABG are $A F$, which is associated with a higher rate of adverse events and cost of care. POAF may occur in between 16\% and 25\% of patients and is associated with an increased mortality risk, stroke and prolonged hospitalization ${ }^{23}$. In a study carried out with 16,169 patients who were followed up for a mean duration of 6 year, El-Chami et al. ${ }^{24}$ reported that the incidence of POAF could predict long-term mortality. Therefore, to ensure favorable outcomes, strategies should be formulated to prevent POAF after cardiac surgery ${ }^{25}$.

The strongest predictors for POAF are age, longer ventilation requirement (not less than 24 hours), utilization of cardiopulmonary bypass and preoperative arrhythmias ${ }^{26,27}$. Kalman et al. ${ }^{28-30}$ reported that the POAF arm of a study on patients who underwent $C A B G$ surgery showed elevated norepinephrine levels, which suggested sympathetic activation.

ECG is essential to detect arrhythmias and ischemic changes. Understanding ischemic changes is important for early detection of cardiac malfunctions. Thanks to the Selvester

\section{Table 1. Baseline characteristics of the study groups}

\begin{tabular}{|l|l|l|l|}
\hline Variables & $\begin{array}{l}\text { Post-operative sinus rhythm } \\
(\mathbf{n = 1 3 0 )}\end{array}$ & $\begin{array}{l}\text { Post-operative atrial fibrillation } \\
(\mathbf{n = 5 0 )}\end{array}$ & p value \\
\hline Age, years & $59.87 \pm 12.45$ & $68.10 \pm 8.83$ & $<\mathbf{0 . 0 0 1}$ \\
\hline Female, $\mathrm{n}(\%)$ & $41(31.5 \%)$ & $10(20.0 \%)$ & 0.124 \\
\hline $\mathrm{BMI}, \mathrm{kg} / \mathrm{m}^{2}$ & $29.01 \pm 5.35$ & $27.97 \pm 4.60$ & 0.227 \\
\hline Diabetes mellitus, $\mathrm{n}(\%)$ & $54(41.5 \%)$ & $26(52.0 \%)$ & 0.206 \\
\hline Hypertension, $\mathrm{n}(\%)$ & $92(70.8 \%)$ & $45(90.0 \%)$ & $\mathbf{0 . 0 0 7}$ \\
\hline Smoking, $\mathrm{n}(\%)$ & $43(33.1 \%)$ & $23(46.0 \%)$ & 0.107 \\
\hline NYHA class & $1.31 \pm 0.23$ & $1.40 \pm 0.31$ & 0.567 \\
\hline Cerebrovascular event history, $\mathrm{n}(\%)$ & $18(13.8 \%)$ & $7(14.0 \%)$ & 0.979 \\
\hline Peripheral vascular disease, $\mathrm{n}(\%)$ & $13(10.0 \%)$ & $5(10.0 \%)$ & 0.998 \\
\hline Beta blocker usage, $\mathrm{n}(\%)$ & $118(90.8 \%)$ & $13(26.0 \%)$ & 0.196 \\
\hline Calcium channel blocker usage, $\mathrm{n}(\%)$ & $22(16.9 \%)$ & $27(54.0 \%)$ & 0.168 \\
\hline ACE/ARB usage, $\mathrm{n}(\%)$ & $63(48.5 \%)$ & $23(46.0 \%)$ & 0.506 \\
\hline Acetylsalicylic/clopidogrel usage, $\mathrm{n}(\%)$ & $56(43.1 \%)$ & & 0.723 \\
\hline $\begin{array}{l}\text { Data are given as mean } \pm \text { SD, } \mathrm{n}, \text { or median (interquartile range). } \\
\text { BMl: Body mass index, ACE: Angiotensin-converting enzyme, ARB: Angiotensin receptor blocker, SD: Standard deviation }\end{array}$ \\
\hline
\end{tabular}


Table 2. Electrocardiographic, echocardiographic and surgical features of the groups

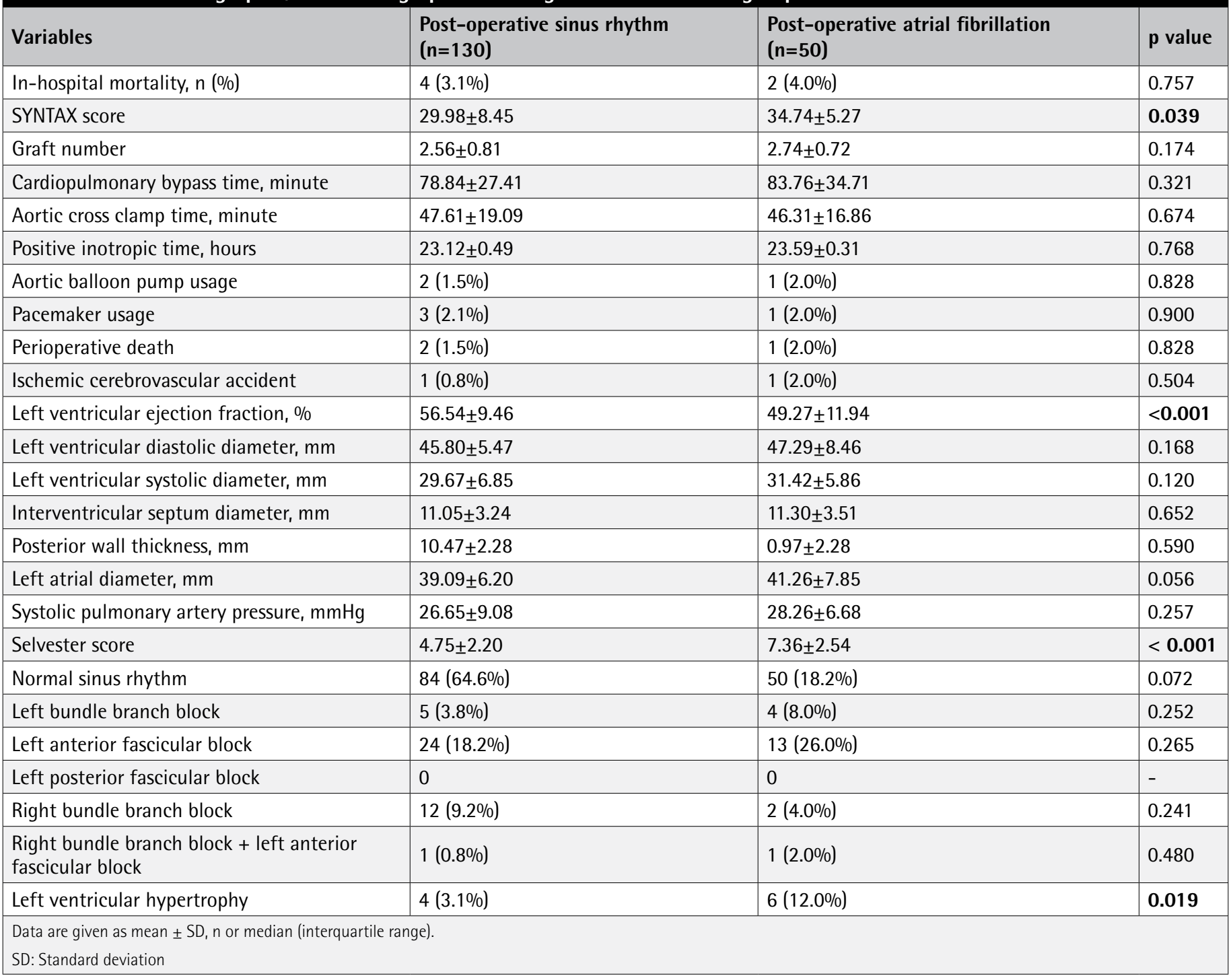

Table 3. Laboratory parameters of the study groups

\begin{tabular}{|c|c|c|c|}
\hline Variables & $\begin{array}{l}\text { Post-operative sinus rhythm } \\
(n=130)\end{array}$ & $\begin{array}{l}\text { Post-operative atrial fibrillation } \\
(n=50)\end{array}$ & $p$ value \\
\hline Glucose, $\mathrm{mg} / \mathrm{dL}$ & $142.54 \pm 67.23$ & $161.46 \pm 80.35$ & 0.121 \\
\hline Creatinine, $\mathrm{mg} / \mathrm{dL}$ & $1.09 \pm 0.33$ & $1.14 \pm 0.29$ & 0.318 \\
\hline WBC, $10^{3} / \mathrm{mm}^{3}$ & $8.89 \pm 4.27$ & $8.46 \pm 2.44$ & 0.419 \\
\hline Hemoglobin, g/dL & $13.77 \pm 1.85$ & $13.74 \pm 1.77$ & 0.922 \\
\hline Platelet, $10^{3} / \mathrm{mm}^{3}$ & $232.34 \pm 63.08$ & $227.64 \pm 72.84$ & 0.669 \\
\hline $\mathrm{Hs}-\mathrm{CRP}, \mathrm{mg} / \mathrm{L}$ & $6.24 \pm 4.85$ & $11.24 \pm 7.54$ & 0.026 \\
\hline Total cholesterol, mg/dL & $196.33 \pm 48.11$ & $196.8 \pm 45.54$ & 0.798 \\
\hline $\mathrm{LDL}-\mathrm{C}, \mathrm{mg} / \mathrm{dL}$ & $129.58 \pm 51.06$ & $126.26 \pm 38.45$ & 0.749 \\
\hline $\mathrm{HDL}-\mathrm{C}, \mathrm{mg} / \mathrm{dL}$ & $42.14 \pm 10.72$ & $41.22 \pm 9.45$ & 0.675 \\
\hline Triglyceride, mg/dL & $147.30 \pm 59.66$ & $150.50 \pm 62.10$ & 0.798 \\
\hline Potassium, mmol/L & $4.43 \pm 0.65$ & $4.57 \pm 0.45$ & 0.747 \\
\hline Magnesium, mmol/L & $0.81 \pm 0.15$ & $0.82 \pm 0.21$ & 0.805 \\
\hline \multicolumn{4}{|c|}{ Data are given as mean $\pm S D, n$, or median (interquartile range). } \\
\hline
\end{tabular}


Table 4. Multivariate logistic regression analysis to predict post-operative atrial fibrillation

\begin{tabular}{|l|l|l|l|l|}
\hline & Univariable OR (95\% CI) & p value & Multivariable OR (95\% CI) & $\mathbf{p}$ value \\
\hline Age & $1.081(1.040-1.124)$ & $<\mathbf{0 . 0 0 1}$ & $1.068(1.017-1.122)$ & $\mathbf{0 . 0 0 8}$ \\
\hline Hypertension & $3.717(1.370-10.087)$ & $\mathbf{0 . 0 1 0}$ & $1.156(0.970-1.376)$ & 0.064 \\
\hline SYNTAX score & $1.290(1.001-1.579)$ & 0.066 & - & - \\
\hline Left ventricular ejection fraction & $0.939(0.908-0.971)$ & $<\mathbf{0 . 0 0 1}$ & $0.939(0.900-0.981)$ & $\mathbf{0 . 0 0 4}$ \\
\hline Hs-CRP, mg/L & $1.025(1.002-1.049)$ & $\mathbf{0 . 0 3 2}$ & $1.016(0.983-1.050)$ & 0.341 \\
\hline Selvester score & $1.524(1.305-1.780)$ & $\mathbf{0 . 0 0 1}$ & $1.602(1.337-1.921)$ & $\mathbf{0 . 0 0 1}$ \\
\hline Left ventricular hypertrophy & $4.295(1.158-15.934)$ & $\mathbf{0 . 0 2 9}$ & $8.368(1.657-42.255)$ \\
\hline Cl: Confidence interval, OR: Odds ratio, Hs-CRP: High-sensitivity C-reactive protein & & & $\mathbf{0 . 0 4 1}$ \\
\hline
\end{tabular}

QRS scoring system, we can place myocardial scar location and detect its size. The highly complex Selvester QRS scoring system was simplified afterwards ${ }^{31}$. This simplified Selvester scoring system is based on the duration of $Q$ and $R$ waves and the ratios of the $R / Q$ and $R / S$ amplitudes in each of 10 leads $(I, I I, a V L, a V F$, and $\mathrm{V} 1-\mathrm{V} 6)$. We took the original and developed systems to compare them in terms of the severity of myocardial injury ${ }^{32}$. However, Selvester scoring could not be used in the presence of right or left bundle-branch-block and left anterior fascicular block. In 2009, the new version of the QRS scoring system was published to measure myocardial scar in the presence of particular abnormalities of interventricular conduction. It was shown that the QRS scoring system was usable with any type of ventricular conduction and applicable to patients with both ischemic and non-ischemic cardiomyopathy ${ }^{33}$. Moreover, Rosengarten et al. ${ }^{34}$ reported that the QRS scoring was very useful to quantify transmural scar and display its association with medium-term mortality risk.

In "the PRIMERI study", Tiffany Win et al. ${ }^{35}$ reported that AFfree patients with structural heart disease (Selvester score $\geq 5$ on ECG) showed abnormal P-terminal force in V1, which was associated with a higher risk of stroke and AF. AF is generally seen more frequently in patient populations with heart failure with a reported incidence rate of $13-27 \% \%^{36}$. Post-myocardial infarction scarring was shown to be a strong predictor of low EF and higher LV volume ${ }^{37}$. Neilan et al. ${ }^{38}$ evaluated the effects of myocardial scarring on AF in hypertrophic cardiomyopathy. This pathology is frequently accompanied by scar formation. Analyses of late-gadolinium enhancement cardiovascular magnetic resonance images showed that AF patients had more extensive LV scarring ${ }^{39}$. Therefore, the Selvester scoring algorithm needs to be evaluated for its association with AF. The Selvester score, therefore, may be used to predict the occurrence of post-operative arrhythmias in patients who have had a recent myocardial infarction and have undergone CABG.

The Selvester score shows excellent correlation with ventricular scar tissue size $e^{40}$. Several factors like tissue damage and infection, which may cause injury physiologically, stimulate inflammation as a defense mechanism. Damaging stimuli may only be eliminated when inflammation occurs on time and in an adequate intensity. Otherwise, the trigger would be persistent with insufficiency of inflammation as a body response. Tissues may more easily heal when injury can actively induce inflammation resolution. Otherwise, any failure may lead to chronic inflammation and prolong the duration of tissue destruction and progressive fibrosis ${ }^{41}$. More research has reported that inflammation has a role in the pathophysiology of $A F$, indicating that the inflammatory process may be a potential therapeutic target ${ }^{42}$. Both electrical and structural remodelings of the atria are the primary pathophysiological mechanisms contributing to AF development and progression. Moreover, AF itself may induce inflammation during atrial remodeling, which maintains the arrhythmia-the so-called "AF begets AF" phenomenon ${ }^{43}$. Ventricular inflammatory activity, measured by ${ }^{18} \mathrm{~F}$-fluorodeoxyglucose positron emission tomography, was reported to be higher by $35 \%$ in 21 patients with AF in comparison to other 21 matched control cases with no $\mathrm{AF}^{17}$. The close relationship between fibrosis and AF may be one of the explanations of why the Selvester score is predictive of POAF.

\section{Study Limitations}

In this study, we utilized a cross-sectional design and sampled a relatively small number of cases. Unfortunately, we had no data on major adverse cardiovascular events during the followup for the patient population that was studied. Therefore, the results of this study need to be confirmed in multi-center prospective longitudinal studies including a greater sample size. The study had a retrospective design. There were no repetitive Sylvester score measurements. Long-term ECG data of the patients were not available. Echocardiograms were performed by different doctors in patients, and the rate of variation might be high. These limitations could have possibly affected the study results.

\section{CONCLUSION}

In this study, the Selvester score was found to be a predictor for POAF. Our study has the potential to predict new risk scores for POAF and be a preliminary step for possible treatments. 
Further studies with multi-center prospective longitudinal designs and larger sample sizes may well-establish the potential relationship of POAF and the Selvester scoring system.

\section{Ethics}

Ethics Committee Approval: The Local Ethics Committee approved our study protocol Süleyman Demirel University Faculty of Medicine Clinical Research and Ethics Committee (decision date: 22.10.2020, number: 323).

Informed Consent: The patients provided written informed consent individually.

Peer-review: Externally peer-reviewed.

\section{Authorship Contributions}

Surgical and Medical Practices: D.U., M.S.K., Concept: D.U., M.S.K., Design: D.U., M.S.K., Data Collection or Processing: D.U., M.S.K., Analysis or Interpretation: D.U., M.S.K., Literature Search: D.U., M.S.K., Writing: D.U., M.S.K.

Conflict of Interest: No conflict of interest was declared by the authors.

Financial Disclosure: The authors declared that this study received no financial support.

\section{References}

1. Jannati M. Atrial Fibrillation Post Coronary Artery Graft Surgery: A Review of Literature. Int J Gen Med. 2019;12:415-20.

2. Aksu T, Güler TE, Mutluer FO, Oto MA. Vagal denervation in atrial fibrillation ablation: A comprehensive review. Anatol J Cardiol. 2017;18:142-8.

3. Gök $G$, Sinan ÜY, Özyüncü N, Zoghi $M$; Elder-Türk Investigators. The prevalence of cardiovascular diseases, risk factors, and cardiovascular drug therapy in very elderly Turkish patients admitted to cardiology clinics: A subgroup analysis of the Elder-Turk study. Turk Kardiyol Dern Ars. 2018;46:283-95.

4. Adalet K. Atrial fibrillation in the elderly. Turk Kardiyol Dern Ars. 2017;45(Suppl 5):75-82.

5. Doğan V, Başaran Ö, Beton O, Tekinalp M, Aykan AÇ, Kalaycıoğlu E, et al. Gender-related differences in presentation and treatment of patients with non-valvular atrial fibrillation: results from RAMSES study. Turk Kardiyol Dern Ars. 2017;45:16-25.

6. Iliescu AC, Salaru DL, Achitei I, Grecu M, Floria M, Tinica G. Postoperative atrial fibrillation prediction following isolated surgical aortic valve replacement. Anatol J Cardiol. 2018;19:394-400.

7. Özin B, Aytemir K, Aslan Ö, Özcan T, Kanadaşı M, Demir M, et al. Clinical practices of the management of nonvalvular atrial fibrillation and outcome of treatment: A representative prospective survey in tertiary healthcare centers across Turkey. Turk Kardiyol Dern Ars. 2018;46:92-102.

8. Erol Ç. Atrial fibrillation, exercise ECHO, OSA, and HOCM. Anatol J Cardiol. 2020;23:307.

9. Türker FS, Erdogan MB, Dogan A. The Factors Affecting Rhythm Control for Cryoablation of Atrial Fibrillation in Mitral Valve Surgery. Braz J Cardiovasc Surg. 2019;34:525-34.

10. Öncel $C R$, Küçük $M$. Predictors of postoperative atrial fibrillation after coronary artery bypass grafting surgery. Anatol J Cardiol. 2017;17:344-5
11. Lowres N, Mulcahy G, Jin K, Gallagher R, Neubeck L, Freedman B. Incidence of postoperative atrial fibrillation recurrence in patients discharged in sinus rhythm after cardiac surgery: a systematic review and meta-analysis. Interact Cardiovasc Thorac Surg. 2018;26:504-11.

12. İscan Ş, Eygi B, Beşir $Y$, Gökalp 0. Perioperative predictors of atrial fibrillation. Anatol J Cardiol. 2018;20:194.

13. Akyüz AR, Korkmaz L. Postoperative atrial fibrillation may be associated with other factors. Anatol J Cardiol. 2016;16:549-50.

14. Temiz A, Gazi E, Güngör $O$, Altun B, Barutcu A, Bekler A, et al. Fragmented QRS and prediction of paroxysmal atrial fibrillation episodes. Pak J Med Sci. 2014;30:862-7.

15. Levy S. Atrial fibrillation, the arrhythmia of the elderly, causes and associated conditions. Anadolu Kardiyol Derg. 2002;2:55-60.

16. Selvester RH, Wagner GS, Hindman NB. The Selvester QRS scoring system for estimating myocardial infarct size. The development and application of the system. Arch Intern Med. 1985;145:1877-81.

17. Mazurek T, Kiliszek M, Kobylecka M, Skubisz-Głuchowska J, Kochman J, Filipiak $\mathrm{K}$, et al. Relation of proinflammatory activity of epicardial adipose tissue to the occurrence of atrial fibrillation. Am J Cardiol. 2014;113:1505-8.

18. Strauss DG, Selvester RH. The QRS complex--a biomarker that "images" the heart: QRS scores to quantify myocardial scar in the presence of normal and abnormal ventricular conduction. J Electrocardiol. 2009;42:85-96.

19. Kirchhof P, Benussi S, Kotecha D, Ahlsson A, Atar D, Casadei B, et al. 2016 ESC Guidelines for the management of atrial fibrillation developed in collaboration with EACTS. Europace. 2016;18:1609-78.

20. Hindricks G, Potpara T, Dagres N, Arbelo E, Bax JJ, Blomström-Lundqvist C, et al. 2020 ESC Guidelines for the diagnosis and management of atrial fibrillation developed in collaboration with the European Association for Cardio-Thoracic Surgery (EACTS). Eur Heart J. 2021;42:373-498.

21. Özcan EE, Görenek B. Lessons from the current European Heart Rhythm Association consensus document on screening for atrial fibrillation. Anatol J Cardiol. 2018;19:222-4.

22. Michelson EL, Morganroth J, MacVaugh H 3rd. Postoperative arrhythmias after coronary artery and cardiac valvular surgery detected by long-term electrocardiographic monitoring. Am Heart J. 1979;97:442-8.

23. Villareal RP, Hariharan R, Liu BC, Kar B, Lee W, Elayda M, et al. Postoperative atrial fibrillation and mortality after coronary artery bypass surgery. J Am Coll Cardiol. 2004:43:742-8.

24. El-Chami MF, Kilgo P, Thourani V, Lattouf OM, Delurgio DB, Guyton RA, et al. New-onset atrial fibrillation predicts long-term mortality after coronary artery bypass graft. J Am Coll Cardiol. 2010;55:1370-6.

25. İşcan Ş, Yürekli i, Çakır H, Peker i, Kestelli M. Atrial fibrillation after cardiac surgery. Anatol J Cardiol. 2015;15:856-7.

26. Folla CO, Melo CC, Silva RC. Predictive factors of atrial fibrillation after coronary artery bypass grafting. Einstein (Sao Paulo). 2016;14:480-5.

27. Gökalp O, Eygi B, Beşir Y, Gürbüz A. Effects of cardiopulmonary bypass on new-onset atrial fibrillation. Anatol J Cardiol. 2016;16:366-7.

28. Erdem K, Oztürk S, Ayhan S, Buğra 0, Bozoğlan O, Tekelioğlu ÜY, et al. Predictive value of aortic knob width for postoperative atrial fibrillation in coronary artery bypass surgery. Anadolu Kardiyol Derg. 2014;14:68-72.

29. Aras D, Özeke Ö. Editorial: Postoperative atrial fibrillation and oxidative stress. Turk Kardiyol Dern Ars. 2014;42:426-8.

30. Kalman JM, Munawar M, Howes LG, Louis WJ, Buxton BF, Gutteridge G, et al. Atrial fibrillation after coronary artery bypass grafting is associated with sympathetic activation. Ann Thorac Surg. 1995;60:1709-15.

31. Bounous EP Jr, Califf RM, Harrell FE Jr, Hinohara T, Mark DB, Ideker RE, et al. Prognostic value of the simplified Selvester QRS score in patients with coronary artery disease. J Am Coll Cardiol. 1988;11:35-41.

32. Seino Y, Staniloff HM, Shell WE, Mickle D, Shah PK, Vyden JK. Evaluation of a QRS scoring system in acute myocardial infarction: relation to infarct size, early stage left ventricular ejection fraction, and exercise performance. Am J Cardiol. 1983;52:37-42. 
33. Strauss DG, Selvester RH, Lima JA, Arheden H, Miller JM, Gerstenblith G, et al. ECG quantification of myocardial scar in cardiomyopathy patients with or without conduction defects: correlation with cardiac magnetic resonance and arrhythmogenesis. Circ Arrhythm Electrophysiol. 2008;1:327-36.

34. Rosengarten JA, Scott PA, Chiu OK, Shambrook JS, Curzen NP, Morgan JM. Can QRS scoring predict left ventricular scar and clinical outcomes? Europace. 2013;15:1034-41.

35. Tiffany Win T, Ambale Venkatesh B, Volpe GJ, Mewton N, Rizzi P, Sharma $\mathrm{RK}$, et al. Associations of electrocardiographic P-wave characteristics with left atrial function, and diffuse left ventricular fibrosis defined by cardiac magnetic resonance: The PRIMERI Study. Heart Rhythm. 2015;12:155-62.

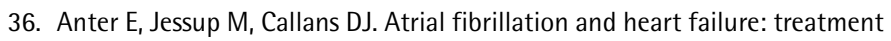
considerations for a dual epidemic. Circulation. 2009;119:2516-25.

37. Lohchab SS, Kumar A. Post-operative atrial fibrillation after off-pump coronary artery bypass grafting. Indian J Thorac Cardiovasc Surg. 2020;36:4-5.
38. Neilan TG, Shah RV, Abbasi SA, Farhad H, Groarke JD, Dodson JA, et al. The incidence, pattern, and prognostic value of left ventricular myocardial scar by late gadolinium enhancement in patients with atrial fibrillation. J Am Coll Cardiol. 2013;62:2205-14.

39. Eroğlu E. Left atrial fibrosis affects left ventricular systolic function in patients with atrial fibrillation. Turk Kardiyol Dern Ars. 2014;42:20-1.

40. Lee DC, Albert CM, Narula D, Kadish AH, Panicker GK, Wu E, et al. Estimating Myocardial Infarction Size With a Simple Electrocardiographic Marker Score. J Am Heart Assoc. 2020;9:014205.

41. Lee SB, Kalluri R. Mechanistic connection between inflammation and fibrosis. Kidney Int Suppl. 2010;22-6.

42. Guo Y, Lip GY, Apostolakis S. Inflammation in atrial fibrillation. J Am Coll Cardiol. 2012;60:2263-70.

43. Savelieva I, Kakouros N, Kourliouros A, Camm AJ. Upstream therapies for management of atrial fibrillation: review of clinical evidence and implications for European Society of Cardiology guidelines. Part I: primary prevention. Europace. 2011;13:308-28. 